\title{
HUBUNGAN ANTARA KESEPIAN DAN KETERLIBATAN AYAH PADA REMAJA
}

\section{Sandra Handayani Sutanto ${ }^{1} \&$ Christiany Suwartono ${ }^{2}$}

${ }^{1}$ Fakultas Psikologi, Universitas Pelita Harapan, Jl. M. H. Thamrin Boulevard 1100, Lippo Karawaci, Jakarta 15811, Indonesia

${ }^{2}$ Fakultas Psikologi, Universitas Katolik Indonesia Atma Jaya, Jl. Jenderal Sudirman 51, Jakarta 12930, Indonesia

Korespondensi:

${ }^{1}$ e-mail: sandra.sutanto@uph.edu; ${ }^{2}$ e-mail: christiany.suwartono@atmajaya.ac.id

\begin{abstract}
Apart from the crowds of the city lives, loneliness is often experienced by teenagers. Previous researched found that peer-and parental-relationships were predictors of loneliness experienced by adolescents. However, no study has specifically examined parental involvement contribution to loneliness of teenagers, especially father involvement. This study aims to discover father participation and how it affects loneliness among adolescents. This is a quantitative survey study using UCLA Loneliness Scale and Father Involvement Scale, participated by 189 adolescents. The results showed that most teenagers felt lonely but their loneliness was not related to father involvement in their lives. The results of additional analysis showed that woman adolescents tended to experience more loneliness compared to man adolescents. Discussion of the study attempts to elaborate the factors related to data collection, developmental stages, and habits of adolescents.
\end{abstract}

Article history:

Received 21 November 2018

Received in revised form 12 March 2019

Accepted 21 March 2019

Available online 29 April 2019

\section{Keywords:}

adolescene;

father involvement;

loneliness

\begin{abstract}
Abstrak - Terlepas dari keramaian perkotaan, kesepian masih melanda para remaja. Penelitian sebelumnya menemukan bahwa relasi dengan teman sebaya dan orang tua merupakan prediktor dari kesepian yang dialami remaja. Namun, belum ada penelitian yang secara khusus meneliti keterlibatan orang tua, terutama keterlibatan ayah. Penelitian ini bertujuan untuk mengetahui partisipasi ayah dalam pengasuhan dan hubungannya terhadap kesepian remaja. Studi survei kuantitatif ini menggunakan UCLA Loneliness Scale dan Father Involvement Scale, pada 189 remaja. Hasil menunjukkan hampir sebagian besar remaja merasakan kesepian, namun tidak berhubungan dengan keterlibatan ayah dalam kehidupan mereka. Hasil analisa tambahan menunjukkan bahwa remaja perempuan cenderung mengalami kesepian dibandingkan remaja laki-laki. Diskusi penelitian mencoba mengelaborasi faktor lokasi pengambilan data, tahapan perkembangan, dan kebiasaan remaja yang memengaruhi hasil.
\end{abstract}

Kata Kunci: remaja; keterlibatan ayah; kesepian 


\section{PENDAHULUAN}

Kehidupan perkotaan identik dengan hal yang dinamis, lengkap, dan terkesan hiruk-pikuk penghuninya. Anggraini (2018) menyatakan bahwa kehidupan perkotaan yang aktif identik dengan kebahagiaan orang-orang yang mendiaminya. Namun, menurut Svendsen (2017), kehidupan di perkotaan juga identik dengan kesepian. Cherry (2013) mendefinisikan kesepian sebagai persepsi bahwa dirinya sendiri dan terisolasi. Kesepian juga didefinisikan sebagai reaksi kognitif dan afektif dikarenakan adanya kesenjangan antara yang diinginkan dengan yang dialami dalam relasi sosial (Anderson, 1999). Kesepian disebabkan oleh beberapa faktor, seperti faktor situasional, yaitu faktor isolasi fisik, berpindah pada lokasi yang baru, perceraian atau kematian seseorang yang signifikan (Cacioppo, Fowler, \& Christakis, 2009). Hawkley dan Cacioppo (2010) menambahkan bahwa kesepian berkaitan dengan kepribadian individu, sehingga individu yang ramah, menyenangkan, teliti, dan tidak memiliki kecenderungan cemas cenderung memiliki skor kesepian yang rendah.

Kesepian bisa dialami oleh siapa saja, mulai dari remaja hingga manula (manusia usia lanjut). Wahyudi (2018) menemukan bahwa berdasarkan Data Status Kesehatan Mental Remaja Indonesia pada tahun 2015, gejala gangguan kesehatan mental yang paling besar adalah kesepian yang dialami sekitar 1.63 juta remaja di Indonesia dengan perbandingan jumlah remaja laki-laki dan perempuan yang hampir sama banyaknya. Remaja merupakan tahapan transisi antara anak-anak dan dewasa. Masa ini identik dengan masa topan badai, sehingga masa remaja disebut sebagai tahapan yang labil dan rentan terhadap berbagai masalah (Santrock, 2010). Dalam menjalani masa topan badainya, remaja dapat menunjukkan beberapa gejala gangguan kesehatan mental, salah satunya adalah kesepian. Remaja yang mengalami kesepian menjadi kurang mampu mengatasi stres ringan dan mengalami kemunduran dari progres masalah sehari-hari (Cacioppo \& Patrick, 2008). Selain itu, kesepian akan membuat individu mengalami reaksi yang intens terhadap hal yang negatif dan kemampuan untuk menikmati hal positif pun menjadi berkurang.

Dalam tahapan perkembangan hidupnya, remaja juga dihadapkan dengan pertanyaan mengenai dirinya dan arah kehidupannya. Erikson (dalam Feist, Feist, \& Roberts, 2013) menyatakan bahwa jika tahapan ini tidak sukses dilalui, maka remaja mengalami kebingungan identitas yang membuat mereka menarik diri, juga mengisolasi diri mereka dari keluarga dan teman. Orang tua memiliki peran yang penting dalam pencarian identitas tersebut (Santrock, 2010), termasuk membantu remaja mengatasi masalah kesepian dan kesehatan mental lainnya. Orang tua yang demokratis dan suportif akan mendorong remaja untuk berpartisipasi dalam pembuatan 
keputusan keluarga. Sedangkan, pola asuh otoriter yang diterapkan oleh orang tua tertentu cenderung akan menghambat remaja untuk berani mengemukakan pendapatnya.

Remaja yang lahir di era 2000-an dikenal sebagai generasi milenial (Howe \& Strauss, 2000). Mereka mengenal teknologi sejak lahir dan merasa nyaman dengan hal tersebut. Berbeda dengan generasi sebelumnya, yaitu imigran ditigal, yang mengalami perkembangan digital dan teknologi pada usia yang tidak muda lagi (Patrikakou, 2016), remaja masa kini tumbuh dan besar di tengah arus perkembangan teknologi dan komunikasi yang begitu cepat dan fasih dalam penguasan teknologi tersebut. Dampak teknologi bagi remaja seperti pedang bermata dua. Pada satu sisi, teknologi memberikan kontribusi yang positif, seperti kemudahan bagi remaja, namun pada sisi yang lain, internet juga membuat aktivitas remaja menjadi terbatas. Asyita (dalam Wahyudi, 2018) menyatakan bahwa internet membuat kepercayaan remaja pada lingkungannya menurun. Secara tidak langsung, hal ini berpotensi membuat remaja mengalami kesepian dan kurang memiliki hubungan yang bermakna dengan sekitarnya.

Rasa kesepian yang dialami oleh remaja juga dapat semakin besar apabila tidak menemukan kehangatan dalam keluarga, misalnya karena kedua orang tua sibuk bekerja sehingga kurang memiliki waktu dan perhatian bagi remaja. Hasil penelitian terdahulu menyatakan bahwa kesepian berasosiasi negatif dengan kehangatan dan keterlibatan orang tua (Rotenberg, 1999). Lebih lanjut, Scharf, Wiseman, dan Farah (2011) menemukan bahwa hangat atau tidaknya pengasuhan berasosiasi dengan tinggi rendahnya kesepian pada remaja.

Sebagian besar remaja di Indonesia masih tinggal dengan orang tuanya hingga usia tertentu sampai mereka memutuskan untuk tinggal terpisah dari orang tua karena berkuliah atau menikah. Keterlibatan orang tua dalam pengasuhan remaja tetap menjadi hal yang krusial, walaupun posisi peran tersebut mulai digantikan oleh kehadiran teman sebaya pada remaja. Orang tua tetap memiliki peran dalam perkembangan remaja (Moretti \& Peled, 2004), terutama sebagai penyedia dukungan sosial untuk remaja (Martin \& Colbert, 1997) dan dalam pembentukan nilai pada remaja (Hurlock, 1999).

Pengasuhan pada anak dan remaja yang dilakukan selama ini lebih memusatkan pengasuhan pada ibu karena ayah lebih berperan sebagai pencari nafkah. Memasuki abad ke-20, peran pengasuhan konvensional bergeser, sehingga ayah juga turut berperan dalam pengasuhan anak (coparent). Pyun (2014) menegaskan bahwa peran ayah sama besarnya dengan peran ibu untuk kesehatan mental anak. 
Peran ayah akan semakin nyata bila ayah terlibat dalam pengasuhan anak. Pleck (2010) mendefinisikan keterlibatan ayah sebagai keterlibatan positif ayah dalam kehidupan anaknya. Lamb, Pleck, Chamov, dan Levine (1987) menyebutkan bahwa keterlibatan ayah memiliki tiga dimensi, antara lain: engagement, yaitu interaksi antara ayah dan anak, seperti mengobrol dan bercakap-cakap dengan remaja ketika mencuci mobil bersama; accesibility, yaitu ayah dapat diakses oleh anak secara fisik dan psikologis, misalnya remaja bisa menghubungi ayah kapanpun melalui telepon atau layanan pesan singkat; dan responsibility, yaitu tanggung jawab ayah dalam pemeliharaan dan kesejahteraan anaknya, seperti pembiayaan sekolah anak dari tingkat dasar hingga jenjang universitas.

Papalia, Olds, dan Feldman (2009) menyebutkan faktor-faktor yang memengaruhi keterlibatan ayah, yaitu motivasi dan komitmen ayah, keyakinan dan kepercayaan diri ayah terkait dengan peran dan keterampilan yang dikuasai, kesuksesan ayah sebagai tulang punggung keluarga, hubungan yang harmonis dengan istri, dan dorongan istri terhadap keterlibatan ayah dalam pengasuhan.

Keterlibatan ayah memiliki dampak pada remaja. Allen dan Daly (2007) menyebutkan keterlibatan ayah memiliki dampak pada aspek kognitif, khususnya pada prestasi akademik, pencapaian karir, dan pencapaian edukasi yang lebih tinggi. Dampak yang kedua pada aspek emosional, yaitu tingkat emotional distress (tekanan emosional) yang rendah, kepuasan hidup yang lebih tinggi, dan tingkat kecemasan yang lebih rendah. Keterlibatan ayah juga memiliki dampak sosial, yaitu dalam hal inisiatif sosial, kompetensi sosial, dan keterlibatan anak dengan orang lain. Dampak terakhir dari keterlibatan ayah ialah berkurangnya dampak negatif perkembangan anak, seperti penyalahgunaan narkoba, perilaku yang nakal, dan mengonsumsi alkohol. Hasil penelitian Mandara dan Murray (2006) menunjukan bahwa keterlibatan ayah memiliki peran yang signifikan terhadap kecenderungan remaja laki-laki untuk tidak menggunakan NAPZA (narkoba, psikotropika, dan zat adiktif) dibandingkan dengan remaja laki-laki yang ayahnya tidak terlibat dalam pengasuhan. Penelitian terakhir menunjukan bahwa keterlibatan ayah yang tinggi secara kualitas juga akan menurunkan internalisasi dan eksternalisasi perilaku bermasalah pada anak pra-remaja (Yoon, Bellamy, Kim, \& Yoon, 2017).

Le Roux (2009) menunjukan bahwa kesepian erat kaitannya dengan sikap remaja pada figur ayahnya. Sikap terhadap ayah menjadi prediktor kesepian yang menonjol pada masa remaja, sehingga sikap yang negatif terhadap ayah meningkatkan perasaan kesepian pada remaja. Penelitian oleh LeRoux tersebut mengonfirmasi penelitian sebelumnya oleh Marcoen, Goossens, dan Caes 
(1987) bahwa semakin remaja mendekati tahapan dewasa muda, maka keterlibatan orang tua akan semakin berkurang dan hal tersebut semakin mengakibatkan kesepian pada remaja karena relasi dengan orang tua yang semakin terbatas. Kedua hasil penelitian dengan kurun waktu yang bervariasi tersebut mendorong peneliti untuk meneliti mengenai keterlibatan ayah dengan kesepian pada remaja pada generasi milenial.

\section{METODE}

\section{Partisipan}

Partisipan dari penelitian ini diambil dengan menggunakan teknik samping aksidental (pengambilan sampel sesuai ketersediaan subjek). Lokasi pengambilan data adalah sekolah-sekolah di Karawaci dan Gading Serpong. Total partisipan dalam penelitian ini sejumlah 201 orang, namun data yang terisi lengkap dan dapat diolah dalam penelitian ini hanya sejumlah 189 partisipan. Para partisipan berusia 14-17 tahun $(M=15.79 ; S D=.84)$, mayoritas berusia 16 tahun $(39.70 \%)$. Partisipan yang termasuk remaja awal (rentang usia 11-14 tahun) berjumlah 9 orang (4.77\%) dan remaja madya (usia 15-18 tahun) berjumlah 180 orang (95.23\%). Sebagian besar partisipan adalah perempuan (53.44\%). Para partisipan pada umumnya tinggal dengan keluarga inti (97.40\%), lainnya tinggal dengan keluarga besar atau kost.

\section{Alat Ukur Penelitian}

Dalam penelitian ini, peneliti menggunakan dua alat ukur, yaitu UCLA Loneliness Scale (Russel, 1996) dan Father Involvement Scale (Greene, Halle, LeMenestrel, \& Moore, 2001) yang diadaptasi sesuai dengan keperluan penelitian.

Skala Kesepian terdiri atas 22 butir yang memiliki kategori jawaban dari Sering (4) hingga Tidak Pernah (1) dengan skor minimal 22 dan skor maksimal 84. Hasil uji reliabilitas menunjukkan koefisien reliabilitas sebesar .875 .

Skala Keterlibatan Ayah terdiri atas 37 butir yang memiliki kategori jawaban dari Sangat Sesuai (5) hingga Sangat Tidak Sesuai (1) dengan skor minimal 37 dan skor maksimal 185. Alat ukur Keterlibatan Ayah memiliki tiga dimensi, antara lain dimensi Father Engagement, yaitu interaksi antara ayah dan anak dengan reliabilitas sebesar .898; dimensi Father Accessibility, yaitu kemudahan bagi anak untuk mengakses ayah secara fisik dan psikologis dengan reliabilitas sebesar 
.714; dan dimensi Responsibility, yaitu tanggung jawab ayah dalam pemeliharaan dan kesejahteraan anak dengan reliabilitas sebesar .801. Secara keseluruhan, reliabilitas dari Skala Keterlibatan Ayah memiliki koefisien reliabilitas sebesar 936. Semakin tinggi skor untuk masing-masing dimensi, maka ayah dipersepsikan anak bahwa ia semakin terlibat berinteraksi dalam kehidupan anak (Father Engagement), semakin mudah diakses oleh anak secara fisik dan psikologis (Father Accesibility), dan semakin bertanggungjawab dalam memelihara dan memperhatikan kesejahteraan anak (Father Responsibility). Skor yang rendah menujukkan hal yang sebaliknya.

\section{Prosedur}

Peneliti melakukan kontak ke beberapa sekolah di area Tangerang. Kemudian, peneliti menjelaskan gambaran umum mengenai penelitian yang dilakukan dan meminta izin untuk melakukan pengambilan data. Setelah izin diberikan, peneliti datang ke sekolah-sekolah yang bersedia ikut berpartisipasi di area Karawaci dan Gading Serpong. Peneliti menjelaskan gambaran umum penelitian di depan kelas dan menanyakan kesediaan siswa/i untuk berpartisipasi. Kemudian, peneliti melakukan pengambilan data pada waktu yang telah disepakati terhadap siswa/i yang bersedia untuk berpartisipasi.

\section{Teknik Analisis}

Pengolahan data pada penelitian ini menggunakan program Microsoft Excel dan SPSS versi 23.0. Pertama-tama, peneliti melakukan uji reliabilitas dengan menggunakan metode konsistensi internal, yaitu dengan Cronbach's Alpha. Kemudian, peneliti melakukan analisis statistik deskriptif terhadap variabel-variabel yang diteliti. Statistik deskriptif ini meliputi tendensi sentral dan dispersi data. Kemudian peneliti melakukan penggolongan sampel penelitian ke dalam dua kategori, yaitu tinggi dan rendah berdasarkan nilai rata-rata yang didapatkan untuk setiap variabel penelitian yang diteliti. Untuk pengujian variabel penelitian, peneliti menggunakan teknik korelasi Pearson Product Moment. Kemudian, peneliti juga melakukan analisis lebih lanjut dengan menggunakan teknik $t$-test independent samples untuk uji perbedaan antara perempuan dan laki-laki terhadap variabel-variabel yang diteliti. 


\section{ANALISIS DAN HASIL}

Berdasarkan tabel 1, variasi keterlibatan ayah dalam hidup partisipan bervariasi. Hal ini dapat dilihat dari nilai standar deviasi variabel keterlibatan ayah. Namun, untuk aksesibilitas, para partisipan cenderung homogen.

Tabel 1.

Gambaran Statistik Deskriptif dan Kategorisasi Variabel

\begin{tabular}{|c|c|c|c|c|c|}
\hline $\begin{array}{c}\text { Statistik } \\
\text { Deskriptif }\end{array}$ & Kesepian & KA_Engagement & KA_Accessibility & KA_Responsibility & $\begin{array}{c}\text { Keterlibatan } \\
\text { Ayah }\end{array}$ \\
\hline Mean & 59.032 & 75.418 & 13.794 & 46.862 & 136.074 \\
\hline Median & 59 & 76 & 14 & 48 & 138 \\
\hline Mode & 60 & 76 & 14 & 50 & 139 \\
\hline$S D$ & 6.138 & 9.979 & 2.206 & 5.870 & 16.419 \\
\hline Minimum & 43 & 36 & 6 & 27 & 75 \\
\hline Maximum & 80 & 95 & 20 & 56 & 170 \\
\hline Tinggi & 52.381 & 52.910 & 58.730 & 55.556 & 51.852 \\
\hline Rendah & 47.619 & 47.090 & 41.270 & 44.444 & 48.148 \\
\hline
\end{tabular}

Keterangan: KA= keterlibatan ayah

Meski sebagian besar partisipan merasa kesepian (52.38\%), data penelitian menunjukan bahwa sebagian besar partisipan juga merasa bahwa secara umum, keterlibatan ayah mereka juga tinggi (51.85\%). Begitu pula dengan aspek engagement, interaksi antara ayah dan anak juga tergolong tinggi (52.91\%) Pada aspek accessibility, akses remaja terhadap ayahnya, baik secara fisik maupun psikologis tergolong tinggi (58.73\%) Kemudian, pada aspek responsibility, tanggung jawab ayah dalam pemeliharaan dan kesejahteraan juga tinggi (55.56\%) dalam sampel kami.

Tabel 2.

Hubungan antara Kesepian, Keterlibatan Ayah, dan Usia

\begin{tabular}{ccccccc} 
& Kesepian & KA_Engagement & KA_Accessibility & KA_Responnsibility & $\begin{array}{c}\text { Keterlibatan } \\
\text { Ayah }\end{array}$ \\
\hline Kesepian & 1 & -.136 & -.022 & -.108 & -.124 \\
Usia & .092 & .027 & .066 & .000 & .025 \\
\hline Ken
\end{tabular}

Keterangan: KA= keterlibatan ayah

Pengujian variabel penelitian ini dilakukan dengan uji korelasi Pearson Product Moment dengan hasil $r(187)=-.124, p>.05, r^{2}=.015$. Hal ini mengindikasikan bahwa tidak ada hubungan antara keterlibatan ayah dengan kesepian pada remaja. Selain itu, tidak ditemukan adanya hubungan 
antara dimensi-dimensi dari keterlibatan ayah dengan kesepian. Hal yang sama juga ditemukan antara usia, baik dengan kesepian maupun dengan keterlibatan ayah beserta dimensi-dimensinya.

Peneliti pun melakukan analisis lebih lanjut, dengan uji perbedaan. Dari tabel 3, ditemukan bahwa ada perbedaan jenis kelamin hanya pada variabel kesepian $(t(187)=2.38, p<.05, d=-.347)$. Remaja perempuan memiliki rasa kesepian yang lebih tinggi dibandingkan dengan remaja laki-laki.

Tabel 3.

Perbedaan Jenis Kelamin dengan Variabel Penelitian

\begin{tabular}{lrrrrrrr} 
& & & Sig. $(2-$ & \multicolumn{2}{c}{ Perempuan $(\boldsymbol{n}=\mathbf{1 0 1})$} & \multicolumn{2}{c}{ Laki-laki $(\boldsymbol{n}=\mathbf{8 8})$} \\
\cline { 6 - 8 } & \multicolumn{1}{c}{$\boldsymbol{t}$} & $\boldsymbol{d f}$ & tailed $)$ & $\boldsymbol{M}$ & \multicolumn{1}{c}{$\boldsymbol{S D}$} & \multicolumn{1}{c}{$\boldsymbol{M}$} \\
\hline Kesepian & 2.376 & 187 & .019 & 60.010 & 6.180 & 57.909 & 5.926 \\
KA_Engagement & .405 & 187 & .686 & 75.693 & 10.753 & 75.102 & 9.061 \\
KA_Accessibility & .057 & 179.945 & .955 & 13.802 & 2.522 & 13.784 & 1.790 \\
KA_Responsibility & .841 & 187 & .401 & 47.198 & 5.860 & 46.477 & 5.892 \\
Keterlibatan Ayah & .554 & 187 & .580 & 136.693 & 17.591 & 135.364 & 15.030 \\
\hline
\end{tabular}

Keterangan: KA= keterlibatan ayah

\section{DISKUSI}

Penelitian kami menemukan bahwa tidak ada hubungan antara kesepian dan keterlibatan ayah pada remaja. Penerimaan dari kelompok (dalam hal ini teman sebaya) memiliki dampak yang lebih besar bagi remaja dan penerimaan ini sangat erat kaitannya dengan kesepian dibandingkan dengan keterlibatan ayah. Dapat dikatakan bahwa pada masa remaja, individu lebih merasa kesepian jika ekspektasi untuk disukai oleh teman sebaya tidak terpenuhi (Liu, Li, Purowono, Chen, \& French, 2015). Hal ini mendukung penelitian Parker dan Asher (1993) yang menyatakan bahwa konflik dengan teman sebaya lebih diasosiasikan sebagai kesepian bagi anak dan remaja. Pada remaja, intimasi dengan teman memprediksi kesepian pada remaja dibandingkan dengan orang tua (Liu, Li, Purwono, Chen, \& French, 2015). Hal inilah yang kami asumsikan terjadi pada sampel kami, sehingga tidak ditemukan hubungan yang signifikan antara keterlibatan ayah dengan kesepian. Para partisipan remaja ini lebih terlibat dengan teman sebayanya.

Hasil penelitian ini pun berbeda dengan penelitian sebelumnya yang menyatakan bahwa prevalensi kesepian cenderung dialami oleh remaja dibandingkan dengan tahapan perkembangan lainnya (Hudson, Elek, \& Campbell-Grossman, 2000). Meskipun sebagian besar remaja (52.38\%) merasa kesepian, namun keterlibatan ayah dalam hidup mereka juga cukup tinggi (di atas 50\%). 
Kemungkinan, hal inilah yang menyebabkan tidak ada hubungan antara kesepian dengan keterlibatan ayah. Penelitian yang dilakukan oleh Le Roux (2009) menyatakan bahwa 79 persen dari remaja yang berusia kurang dari 18 tahun mengalami kesepian. Dalam penelitian tersebut, kesepian remaja dikaitkan dengan sikap negatif remaja terhadap ayah yang diukur melalui aspek kognitif, yaitu skema mengenai keterlibatan ayah; aspek afektif, yaitu emosi yang dibarengi dengan sikap tertentu terhadap ayah; dan aspek konatif, yaitu sikap yang melibatkan intensi untuk bertindak.

Selain itu, hasil penelitian kami tidak menemukan adanya hubungan antara usia remaja dengan kesepian. Hal ini mendukung penelitian yang dilakukan Van Roekel, Scholte, Verhagen, Goossens, dan Engels (2010) pada remaja di sekolah menengah atasyang menyatakan bahwa seiring bertambahnya usia remaja, maka tingkat kesepian akan menurun. Ladd dan Ettekal (2013) juga menemukan bahwa remaja di Amerika mengalami penurunan kesepian di rentang usia remaja akhir. Partisipan pada penelitian ini berusia 14 hingga 17 tahun $\left(M_{\text {usia }}=15.79\right)$ dan termasuk dalam tahapan usia remaja menengah (Steinberg, 2017), sehingga kesepian tidak begitu dialami lagi oleh mereka.

Lebih lanjut, hasil penelitian ini juga menunjukan bahwa tidak ada hubungan yang signifikan antara keterlibatan ayah dengan perbedaan jenis kelamin responden. Keterlibatan ayah kurang lebih setara pada kehidupan remaja perempuan dan laki-laki, baik dari sisi engagement sebagai bentuk interaksi ayah dengan remaja dengan menghabiskan waktu bersama, accessibility sebagai kemudahan untuk mengakses ayah secara fisik dan psikologis, dan responsibility ayah dalam kehidupan remaja.

Analisa tambahan pada penelitian ini menyatakan bahwa rata-rata kesepian yang dialami oleh remaja perempuan lebih tinggi dibandingkan dengan remaja laki-laki. Nilai rata-rata kesepian pada remaja perempuan sebesar 60.01, sedangkan pada remaja laki-laki sebesar 57.90. Hal ini sejalan dengan penelitian yang dilakukan oleh Killeen (1998) dan Shukla dan Kang (2017) pada remaja di India. Pemaknaan kesepian antara perempuan dan laki-laki pada usia yang lebih muda relatif sama, namun mengalami pengalaman dan pemaknaan yang berbeda pada masa remaja (Ebesutani dkk.,2012). Panayiotou, Panteli, dan Theodorou (2016) menyatakan bahwa kesepian pada perempuan disebabkan oleh rendahnya self-esteem (keberhargaan diri) dan keterampilan sosial yang rendah, sedangkan kesepian pada laki-laki disebabkan oleh kecemasan karena kepekaan yang berlebihan (anxiety sensitivity). Dengan demikian, pada masa remaja, khususnya perempuan di Indonesia dan India rentan mengalami kesepian, meskipun tinggal di area urban yang 
memungkinkan untuk memiliki interaksi lebih luas dan memiliki koneksi dengan internet. Bentuk kesepian pada remaja ini berbagai macam, mulai dari perasaan bosan, perasaan gagal, kehilangan makna, dan kekosongan di dalam diri. Hasil penelitian ini berbeda dengan hasil penelitian Panayioutou, Panteli, dan Theodorou (2016) yang justru menemukan bahwa kesepian pada mahasiswa laki-laki lebih besar daripada mahasiswa perempuan.

Dalam proses identifikasi pada remaja, perilaku yang dimunculkan, seperti pemikiran, emosi, dan intensi diarahkan dari sikap remaja terhadap salah satu atau kedua orang tua (Le Roux, 2009). Ayah memiliki peran utama dalam perkembangan anak secara sosial, emosional, dan intelektual. Le Roux juga menambahkan bahwa identifikasi terhadap peran gender dan kemampuan untuk membentuk hubungan romantis dipelajari oleh seorang remaja laki-laki dari ayahnya. Kehilangan figur ayah, baik karena perceraian, kematian, dan kurangnya keterlibatan ayah, juga dapat berujung pada kesepian. Hampir semua partisipan dalam penelitian tinggal bersama dengan keluarga inti (ayah, ibu, dan saudara kandung), sehingga figur ayah dalam kehidupan sehari-hari mereka ada dan stabil. Hal ini yang berkontribusi terhadap tidak ada hubungan antara keterlibatan ayah dengan kesepian. Kemudian, Jayson (2019) juga menyatakan bahwa kesepian lebih rentan dialami oleh remaja yang tidak tinggal dengan keluarganya, misalnya dengan berpindah kota untuk meneruskan studi.

Secara demografis, remaja yang menjadi partisipan penelitian ini bersekolah dan bertempat tinggal di Karawaci dan Gading Serpong yang dekat dengan kota metropolitan Jakarta sebagai kawasan urban. Secara tidak langsung, kondisi dan gaya hidup Jakarta turut memengaruhi remaja di kawasan ini menjadi lebih hidup dan dinamis. Olivia (2011) menjelaskan bahwa pola interaksi masyarakat urban cenderung tanpa penghayatan, basa-basi, dan hanya dalam sekejap. Dalam satu hari, masyarakat urban berinteraksi dan bersinggungan dengan banyak orang, baik yang dikenal maupun tidak dikenal. Hal-hal ini membuat remaja pun tidak sempat merasakan kesepian akibat banyaknya stimulus, baik dari lingkungan fisik maupun sosial.

Shukla dan Kang (2017) menunjukan bahwa tingkat kesepian pada remaja yang tinggal di pedesaan lebih tinggi daripada remaja yang tinggal di kota besar atau wilayah urban, yang hidup dengan lebih banyak akses pada fasilitas untuk kegiatan sosial dan rekreasional, seperti pusat perbelanjaan, sehingga peluang untuk berinteraksi dengan orang lain lebih besar dibandingkan dengan di desa.

Remaja di area urban juga lebih banyak berinteraksi dengan menggunakan internet. Data dari Asosiasi Penyelenggara Jasa Internet Indonesia (APJII) pada tahun 2017 menyebutkan bahwa 
jumlah remaja yang menggunakan internet diperkirakan sebesar 23.9 juta jiwa dengan tujuan untuk chatting dan menggunakan media sosial. Penggunaan internet pada area urban sebesar 72.41 persen, di mana sekitar 103 juta individu di area urban aktif menggunakan internet. Hasil penelitian korelasional dan eksperimental mengenai sosial media menunjukkan bahwa penggunaan sosial media meningkatkan perasaan terkoneksi dengan orang lain dan meningkatkan perasaan mendapatkan dukungan sosial (Clark, Algoe, \& Green, 2017). Lee, Noh, dan Koo (2013) juga menyatakan bahwa perilaku mengungkap diri (self-disclosing) di internet meningkatkan well-being (kesejahteraan) dan dukungan sosial yang dirasakan. Berbeda dengan hasil penelitian sebelumnya, internet membantu remaja agar tidak merasa kesepian karena internet membuat perasaan terkoneksi dengan orang lain di sekitarnya, termasuk dengan ayah. Keterikatan dalam keluarga menjadi lebih mudah dengan penggunaan internet dan telepon selular, juga memudahkan untuk berkoordinasi dalam satu keluarga, lebih intensif dalam berkomunikasi, berbagi berita, dan hal-hal lain yang terjadi dalam kehidupan sehari-hari (Kennedy, Smith, Wells, \& Wellman, 2008). Kanter, Afifi, dan Robins (2012) membuktikan bahwa hubungan antara orang tua dan anak dengan menggunakan platform media sosial, seperti Facebook terbukti meningkat dan dapat menurunkan konflik, juga menumbuhkan kedekatan antara orang tua dan anak.

Hasil penelitian ini tidak menunjukan adanya hubungan yang signifikan antara keterlibatan ayah dengan kesepian pada remaja. Hal ini mungkin dikarenakan sampel penelitian kami yang cenderung homogen, baik dari segi usia maupun lingkungan tempat tinggal. Para partisipan berusia antara 14 - 17 tahun, di mana mereka tergolong pada masa remaja madya (menengah). Para partisipan ini tinggal di lingkungan yang sama, sehingga variasi area kurang. Kedua hal ini membuat sampel penelitian ini kurang mewakili populasi remaja yang lebih besar.

Dari hasil penelitian ini, hanya 33 persen aktivitas yang dilakukan oleh remaja yang benarbenar melibatkan interaksi dengan ayah, seperti mengobrol dan bercanda. Penelitian ini tidak menanyakan mengenai kuantitas aktivitas yang spesifik dan kualitas aktivitas remaja dengan ayah. Penelitian ini juga tidak mengeksplorasi kegiatan waktu luang yang dilakukan remaja dengan teman sebaya. Oleh karena itu, penelitian berikutnya perlu untuk meneliti dengan lebih detail mengenai relasi dan kualitas aktivitas dengan ayah dan teman-teman sebaya. 


\section{SIMPULAN DAN SARAN}

\section{Simpulan}

Kesimpulan dari penelitian ini adalah tidak adanya hubungan antara kesepian dan keterlibatan ayah pada remaja. Partisipan remaja, khususnya remaja perempuan dalam penelitian ini mengalami kesepian, namun kesepian mereka tidak berhubungan dengan keterlibatan ayah dalam kehidupan mereka. Hasil ini tidak sesuai dengan teori awal yang menyatakan bahwa remaja mengalami kesepian dan hal ini terkait dengan keterlibatan ayah dalam pengasuhan. Faktor prediktor kesepian pada remaja urban kemungkinan lebih disebabkan oleh penerimaan teman sebaya, akses untuk berelasi di area urban, hingga penggunaan internet.

\section{Saran Teoretis}

Kesepian pada remaja menarik untuk diteliti lebih lanjut, terutama karena kesepian menjadi salah satu gejala gangguan kesehatan mental. Penelitian selanjutnya dapat meneliti mengenai peran kelompok teman sebaya dengan kesepian pada remaja. Selain itu, penelitian selanjutnya juga dapat meneliti remaja yang tinggal di daerah pedesaan karena kesepian tidak hanya dialami oleh remaja di kawasan urban saja.

Sampel pada penelitian ini lebih banyak mewakili remaja usia madya (menengah), tetapi tidak mencakup remaja awal dan remaja akhir. Untuk penelitian berikutnya, disarankan untuk mengambil sampel mulai dari remaja awal hingga remaja akhir, sehingga didapatkan gambaran perkembangan remaja secara utuh.

Kemudian, penelitian berikutnya dapat menggali informasi yang lebih spesifik mengenai kuantitas waktu luang dari remaja, deskripsi kualitas hubungan dengan ayah, pola interaksi dalam keluarga, dan aktivitas dengan teman sebaya. Lalu, melihat perkembangan teknologi, ada kemungkinan remaja menghabiskan waktunya dengan memanfaatkan internet dan gawai, baik berupa komputer/laptop maupun telepon pintar. Hal ini dapat diteliti lebih dalam guna menjelaskan fenomena kesepian yang dialami oleh remaja.

\section{Saran Praktis}

Kesepian pada remaja perlu mendapat perhatian khusus dari pihak-pihak yang terlibat dengan remaja. Sebagai contoh, untuk pihak sekolahagar menyediakan berbagai kegiatan ekstrakurikuler yang dapat mendorong para siswa dan siswi untuk berkumpul bersama teman-teman sebayanya, 
serta berkreasi dengan tujuan menyalurkan bakat dan minat mereka. Meskipun saat ini sebagian besar sekolah - sekolah mewajibkan siswa-siswinya untuk mengikuti kegiatan ekstrakulikuler, diharapkan guru-guru tetap memerhatikan keterlibatan siswa-siswinya dalam kegiatan ekstrakurikuler ini. Selain itu, model-model dukungan sosial bagi remaja dapat dikembangkan, misalnya dengan pelatihan dasar-dasar peer counseling (konseling teman sebaya) bagi remaja. Dengan demikian, jika terdapat masalah, mereka dapat menjadi teman yang empatik bagi sesama.

\section{REFERENSI}

Anderson, C. A. (1999). Attributional style, depression, and loneliness: A cross-cultural comparison of American and Chinese students. Personality and Social Psychology Bulletin, 25(4), 482499. doi : $10.1177 / 0146167299025004007$.

Anggraini, A. P. (2018). Hidup di kota besar lebih bahagia, benarkah? Kompas. Ditemu kembali dari https://lifestyle.kompas.com/read/2018/07/18/144100020/hidup-di-kota-besar-lebihbahagia-benarkah

Asosiasi Penyedia Jasa Internet Indonesia. (2017). Infografis: Penetrasi dan perilaku pengguna internet di Indonesia. Ditemu kembali dari https://apjii.or.id/survei2017

Allen, S., \& Daly, K. (2007). The effect of father involvement: An updated research summary of the evidence. Canada: University of Guelph.

Cacioppo, J. T., \& Patrick, W. (2008). Loneliness: Human nature and the need for social connection. New York, NY: W.W. Norton \& Company.

Cacioppo, J. T., Fowler, J. H., \& Christakis, N. A. (2009). Alone in the crowd: The structure and spread of loneliness in a large social network. Journal of Personality and Social Psychology, 97(6), 977-991. doi: 10.1037/a0016076

Cherry, K. (2013). Loneliness: Causes, effects, and treatment for loneliness. Ditemu kembali dari http://www.nyc.gov/html/nypd/downloads/pdf/early_intervention/psychology_article.pdf

Clark, J. L., Algoe, S. B., \& Green, M. C. (2017). Social network sites and well-being: The role of social connection. Current Directions in Psychological Science, 27(1), 32-37. doi: $10.1177 / 0963721417730833$

Ebesutani, C., Drescher, C. F., Reise, S. P., Heiden, L., Hight, T. L., Damon, J. D., \& Young, J. (2012). The importance of modeling method effects: Resolving the (uni)dimensionality of the 
loneliness questionnaire. Journal of Personality Assessment, 94(2), 186-195. doi: 10.1080/00223891.2011.627967.

Feist, J, Feist, G. J., \& Roberts, T. (2013). Theories of personality (8th ed.). New York, NY: McGraw-Hill.

Greene, A. D., Halle, T. G., LeMenestrel, S. M., \& Moore, K. A. (2001). Measuring father involvement in young children's lives: Recommendations for a fatherhood module for the ECLS-B. Washington, D.C: National Center for Education Statistics.

Hawkley, L. C., \& Cacioppo, J. T. (2010). Loneliness matters: A theoretical and empirical review of consequences and mechanisms. Annals of Behavioral Medicine, 40(2), 218-227. doi: 10.1007/s12160-010-9210-8

Howe, N., \& Strauss, W. (2000). Millennials rising: The next great generation. New York, NY: Vintage Books.

Hudson, D. B., Elek, S. M., \& Campbell-Grossman, C. (2000). Depression, self-esteem, loneliness, and social support among adolescent mothers participating in the new parents projects. Adolescence, 35(139), 445-453.

Hurlock, E. B. (1980). Developmental psychology: A life-span approach (5th ed.). United States, US: McGraw-Hill College.

Jayson, S. (2019). Despite social media, generation Z, millennials report feeling lonely. Ditemu kembali dari https://www.nbcnews.com/health/health-news/despite-social-media-generationZ-millennials-report-feeling-lonely-n980926

Kanter, M., Afifi, T., \& Robbins, S. (2012). The impact of parents "friending" their young adult child on Facebook on perceptions of parental privacy invasions and parent-child relationship quality. Journal of Communication, 62(5), 900-917. doi: 10.1111/j.1460-2466.2012.01669.x

Kennedy, T. L. M., Smith, A., Wells, A. T., \& Wellman, B. (2008). Networked families. Ditemu kembali dari https://www.issuelab.org/resources/10380/10380.pdf

Killeen, C. (1998). Loneliness: An epidemic in modern society. Journal of Advanced Nursing, 28(4), 762-770. doi: 10.1046/j.1365-2648.1998.00703.x

Ladd, G. W., \& Ettekal, I. (2013). Peer-related loneliness across early to late adolescence: Normative trends, intra-individual trajectories, and links with depressive symptoms. Journal of Adolescence, 36(6), 1269-1282. doi: 10.1016/j.adolescence.2013.05.004

Lamb, M. E., Pleck, J. H., Chamov, E. L., \& Levine, J. A. (1987). A biosocial perspective on paternal behavior and involvement. Dalam J. B. Lancaster, J. Altmann, A. S. Rossi, \& L. R. 
Sherrod (Eds.), Parenting across the lifespan: Biosocial dimensions (hlm. 111-142). Hawthrone, NY: Aldine Publishing Co.

Lee, K. T., Noh, M. J., \& Koo, D. M. (2013). Lonely people are no longer lonely on social networking sites: The mediating role of self-disclosure and social support. Cyberpsychology, Behavior, and Social Networking, 16(6), 413-418. doi: 10.1089/cyber.2012.0553

Le Roux, A. (2009). The relationship between adolescents' attitude toward their fathers and loneliness: A cross-cultural study. Journal of Child and Family Studies, 18(2), 219-226. doi: $10.1007 / \mathrm{s} 10826-008-9222-1$

Liu, J., Li, D., Purwono, U., Chen, X., \& French, D. C. (2015). Loneliness of Indonesian and Chinese adolescents as predicted by relationships with friends and parents. Merrill-Palmer Quarterly, 61(3), 362-382. doi: 10.13110/merrpalmquar1982.61.3.0362

Mandara, J., \& Murray, C. B. (2006). Father's absence and African American adolescent drug use. Journal of Divorce \& Remarriage, 46 (1-2), 1-12. doi: 10.1300/J087v46n01_01

Marcoen, A., Goossens, L., \& Caes, P. (1987). Loneliness in pre-through late adolescence: Exploring the contributions of a multidimensional approach. Journal of Youth and Adolescence, 16(6), 561-577. doi: 10.1007/BF02138821

Martin, C. A., \& Colbert, K. K., (1997). Parenting: A life span perspective. New York, NY: McGraw-Hill Book Company.

Moretti, M. M., \& Peled, M. (2004). Adolescent-parent attachment: Bonds that support healthy development. Paediatrics \& Child Health, 9(8), 551-555. doi: 10.1093/pch/9.8.551

Olivia, N. R. (2011). Gambaran kehidupan kota urban ditinjau dari unsur intrinsik lima cerpen netzliteratur: Sebuah pendekatan sosiologi sastra (Skripsi tidak dipublikasikan). Universitas Indonesia, Indonesia.

Panayiotou, G., Panteli, M., \& Theodorou, M. (2016). Predictors of loneliness in a sample of college men and women in Cyprus: The role of anxiety and social skills. Psychology, Community, \& Health, 5(1), 16-30. doi:10.5964/pch.v5i1.142

Papalia, D. E., Olds, S. W., \& Feldman, R. D. (2009). Human development: Perkembangan manusia (10th ed.). Jakarta: Salemba Humanika.

Parker, J. G., \& Asher, S. R. (1993). Friendship and friendship quality in middle childhood: Links with peer group acceptance and feelings of loneliness and social dissatisfaction. Developmental Psychology, 29(4), 611-621. doi: 10.1037/0012-1649.29.4.611 
Patrikakou, E. N. (2016). Parent involvement, technology, and media: Now what? The School Community Journal, 26(2), 9-24.

Pleck, J. H. (2010). Paternal involvement: Revised conceptualization and theoretical lingkages with child outcomes. Dalam M. E. Lamb (Eds.), The role of the father in child development (hlm. 58-93). New Jersey, US: John Wiley \& Sons Inc.

Pyun, Y. S. (2014). The influence of father-child relationship on adolescents' mental health (Unpublished theses). Minnesota State University, Mankato.

Rotenberg, K. J. (1999). Parental antecedents of children's loneliness. Dalam K. J. Rotenberg \& S. Hymel (Eds.), Loneliness in childhood and adolescence (hlm.176-200). Cambridge: Cambridge University Press.

Russell, D. (1996). UCLA loneliness scale (version 3): Reliability, validity, and factor structure. Journal of Personality Assessment, 66(1), 20-40. doi: 10.1207/s15327752jpa6601_2

Santrock, J. W. (2010). Adolescence (13th ed.). New York, NY: McGraw-Hill.

Scharf, M., Wiseman, H., \& Farah, F. (2011). Parent-adolescent relationships and social adjustment: The case of a collectivistic culture. International Journal of Psychology, 46(3), 177-190. doi: 10.1080/00207594.2010.528424

Shukla, P., \& Kang, T. K. (2017). Perceived loneliness among rural and urban adolescents: A comparative study. Indian Journal of Positive Psychology, 8(3), 386-388.

Steinberg, L. (2017). Adolescence (11th ed.). New York, NY: McGraw-Hill Education.

Svendsen, L. (2017). A philosophy of loneliness. London, UK: Reaktion Books Ltd.

Van Roekel, E., Scholte, R. H. J., Verhagen, M., Goossens, L., \& Engels, R. C. M. E. (2010). Loneliness in adolescence: Gene $\mathrm{x}$ environment interactions involving the serotonin transporter gene. Journal of Child Psychology and Psychiatry, and Allied Discplines, 51(7), 747-754. doi: 10.1111/j.1469-7610.2010.02225.x

Wahyudi, M. Z. (2018). Dengarkan remaja! Kompas. Ditemu kembali dari https://kompas.id/baca/utama/2018/10/11/dengarkan-remaja/

Yoon, S., Bellamy, J. L., Kim, W., \& Yoon, D. (2017). Father involvement and behavior problems among preadolescents at risk of maltreatment. Journal of Child and Family Studies, 27(2), 494-504. doi: 10.1007/s10826-017-0890-6 